\title{
Thinking on Reform and Innovation of College Dance Education under New Media Environment
}

\author{
Yuan Chen \\ College of music, Ningxia University, Yinchuan, 750021, China
}

Keywords: New media, College dance, Educational reform

\begin{abstract}
The spread of social dance art is vital work in the process of college dance education. Dance talents cultivated not only have strong adaptive capacity, but also can combine skills and techniques and social demands very well. Talents of such type are also called as dance art. In particular, they have made great contributions to college dance course. Therefore, Chinese dance art is so popular in various countries. Starting with new media reform, this paper deeply discusses the reform of college dance education.
\end{abstract}

\section{Introduction}

In terms of the nature of college dance education, traditional education generally involves oral transmission. Its teaching contents are composed of commence sense about dance and folk dance. Such traditional educational pattern can no longer meet the demand of contemporary social development. To adapt to various changing demands and connect education and teaching with social practice better under the environment of new media, we must reform the educational pattern of colleges and universities deeply.

\section{Influence of new media on education and teaching}

Update dance style. According to the starting point and foothold of education, it is people-oriented. Good education requires constant innovation and development. Under the environment of rapid development of media in the current society, various kinds of information are spread rapidly and methods for obtaining information and the quantity of information increase constantly. This will definitely influence the normal life and learning concept of people. Demands for knowledge generally reflect some new characteristics. To further meet various demands of educators, it is necessary to update their concept and emancipate them from traditional thinking before the reform of school-running system by educational subject. First, the direction of teaching reform should be guided by various demands of the society. Currently, each field of social dance art is developing rapidly and the social foundation of dance is constantly expanded. We can see dances represented by square dance which can be seen in the park in many regions. Dance development also involves commercialized development pattern. In recent years, specialized troupes at each level in China have launched many excellent dances and further activated each type of business cultural performance. Moreover, many dancers are known and favored by people. Dance music has further broken through the traditional way and is developing rapidly towards diversification. Some new dances are constantly emerging under such environment. Organizing personnel of college dance education must attach importance to changes of these dance styles essentially. Only with sharp insight can they keep pace with the development of the era.

Importance of dance education. College education is different from other basic education. The objective of college education is to cultivate professional technical talents. Such training mode mainly accords with social development demands and allows talents cultivated to serve the society better and gain recognition of all sectors of the society. For students of college dance education, it is not enough to simply learn dance skills. It is also necessary to spread dance skills learnt effectively. The spread might cover a large area and have direct influence on dance level of the public. Therefore, dance educators shoulder heavy responsibilities. 
Innovation of education system. Media updating work has vital significance for the expansion of teaching thought. The basic foundation of the innovation of education system is the innovation of educational thinking and the source of innovation is concretization of abstract thinking. Fast spread, large capacity and various types of social information under the contemporary media environment have undoubtedly brought greater challenges as well as development opportunity to college education. To adapt to demands of era development better, the thinking of educational subjects should advance with the times and contents of conception should be more concrete. They should be able to achieve objectives of college education and meanwhile evaluate the result of some reforms objectively. Generally, people attach importance to essential details of education but neglect education in spiritual field. In fact, a series of reform measures should be established in the development field of educational subject. The development of dance course has close connection with mass base and college education is their bridge. Therefore, changing educational thinking with the times is the key first step to gain excellent teaching achievements.

\section{Transformation of educational mode under new media environment}

Optimization of curriculum structural system of each type. According to characteristics of college education in various aspects, it is required to optimize curriculum structure of each type according to specific circumstance. In traditional teaching process, the authoritativeness of education generally determines the keynote of course layout to a certain extent. Contents of education in colleges and universities are largely identical with minor differences. The setting of educational mode of this type has formed a unified, standard and scientific operating mechanism within the specified scope, but neglected the inner voice of educational population essentially. Learners involved in college education meet difficulties in various aspects in the learning process due to limitations such as older age. Meanwhile, specific contents of education required have great differences due to differences in learning goal. This requires teaching mode to manifest level and difference to a certain extent and be adjusted according to different conditions of students.

Full use of advantages of new media. Deficiencies of traditional teaching can be covered through advanced technologies and interactive features of new media. Compared to traditional media, new media has a greatly increased speed and wide coverage and provides an all-round spreading interaction. New media can make the communication among people more convenient and fast and allow solving various problems met in life easily. Advantages of new media are very important in the field of dance education. Full use of various advantages of new media can make teaching contents richer and easy to operate. For example, the application of multimedia teaching in college dance teaching process is a teaching method worth being promoted. Educational structural system of this type collects effective educational resources of each type and dance consultation widely based on advanced media platform and strengthens teaching effects through text, audio, picture and video. This teaching method is more advanced. In addition, remote education can be implemented to a certain scale with the help of internet and new media in the process of college education. Remote education can further provide help for students' learning and improve their learning efficiency without limitations of place and time. Meanwhile, it is required to make full use of advantages of new media transmission, master the development trend of dance in time and further upgrade teaching contents and mode so as to adapt to social demands in various aspects. The development of new media has brought great pressure to dance teaching and meanwhile provided development opportunities for dance education. In recent years, music culture has developed with a staggering rate. Various types of music have integrated under the situation of constant development of multiple media. Some old music styles have been abandoned and various types of music form new music style in the collision process. This is manifested in music field and often occurs in dance field. The latest development direction of dance art has certain connection with college dance teaching contents. Therefore, some people become interested in dance when reading some information about dance. Therefore, educational development should advance with the development of the times in whichever aspect. Educators should make full use of media information to master the trend of media in time and be able 
to comply with the change of era development so as to solve various problems met in the teaching process.

\section{Reform of educational and teaching structural system under new media environment}

Transformation of educational system. Educational system is the core part of teaching system, which is generally accepted as the base of teaching implementation. In the teaching process of regular higher educational institutions, educational system has gradually turned into credit system mode from traditional educational mode. In the process of college education, semester system educational mode is also adopted and meanwhile planned teaching practice is used as the standard system for educational implementation. Such system has many similarities with elementary educational system in various aspects. However, discipline division is more and more sophisticated in contemporary education process and students have more and more choices. Credit system education might be able to solve various problems encountered in education under such educational background. According to requirements of dance major in college education, as there are many modern dance art types such as ballet, jazziness and folk dance, how to help students choose the appropriate dance is very important. Under the current educational system structure, the explanation of one or more dances cannot meet demands of students in various aspects to a certain extent due to time limit. Credit system can coordinate learners and study and further meet demands of students in various aspects under the current educational system structure. Educational structure of credit system centers on course selection. Students choose courses freely and their learning situation is evaluated with the final credit. If such educational system is used in dance major of college education, certain advantages will be manifested in the following aspects: first, as students can choose some courses based on their interests and hobbies under teaching structure of credit system, some students favoring dance can choose to learn dance. Therefore, dance teaching can be more pertinent and meanwhile gain significant teaching achievements. Second, credit system can improve teachers' awareness of competition. They can gain students' favor and selection through excellent dancing techniques and high-level teaching method. This will impose great teaching pressure on teachers invisibly and make them improve their teaching level and quality consciously. Third, better learning objectives can be realized effectively. It can stimulate students' consciousness and interest in dance learning, their inner potentials and unlimited learning enthusiasm within limited time and meanwhile establish a good atmosphere for communication invisibly. In addition, credit system makes people see various advantages of the educational system in traditional practice process. In the contemporary era, colleges and universities in China have not made full use of credit system educational mode mostly due to limitations of school-running conditions. However, according to the influence of contemporary new media in various aspects, credit system educational mode should be implemented as early as possible so as to improve teaching effects and promote the development of colleges and universities better.

Innovation of teaching methods. Teaching methods should be innovated. In terms of teaching methods, the teaching method of teachers' knowledge instruction cannot improve students' learning ability. It is required to transform traditional teaching method into modern teaching method, use methods of research, discussion and exploration in the teaching process and endeavor to introduce various flexible teaching methods into the classroom, make full use of modern educational technologies, implement dance education in many ways, change traditional teaching mode and use auxiliary teaching tools such as multimedia, meanwhile use video teaching method, save some precious materials in time in case for future use, and strengthen teaching team in various aspects. First, strengthen the construction of teaching team of dance major in colleges and universities, optimize teacher resources of dance in various aspects, mainly including age, title and education structure, make full use of market management mechanism, arouse the initiative of each subject in participation, standardize and manage teacher mechanism and recruit teachers in strict accordance with teacher recruitment system. Second, incomes of dance teachers should be further stabilized so as to strengthen attraction power of the profession, prevent the loss of teacher resources and promote constant development of education essentially. It is necessary to establish a profound atmosphere of dance teachers in the society, make all sectors of the society pay attention to and respect the 
profession of teachers and encourage and support more excellent young workers to throw themselves into education.

\section{Conclusion}

In conclusion, college dance education has cultivated a lot of excellent talents for the society with the rapid development of education and teaching. They might be professional talents, professional dance educators or researchers of dance art. Whatever industry they are engaged in, they make contributions to the construction of the society. However, with the rapid development of new media, corresponding reform must be conducted if college dance educators want to continue to cultivate a lot of excellent professional talents for the society. Only when adapting to social development demands actually can professional talents required by the society be cultivated.

\section{Acknowledgments}

This paper is a school-level topic. Topic name: Study on Teacher Training Quality of Ningxia Higher Teacher Dance Education, No: SK1329.

\section{References}

[1] Z.X. Zhang. Analysis on Origin, Development and Trait of Dance Art under New Media. Journal of Beijing Dance Academy, 2009, (04).

[2] L.M. Kong. Exploration on Development of Adult Education in Local Colleges and Universities in New Media Era. Continuing Education, 2010, (10).

[3] Z.X. Zhang. Analysis on Typology of Dance Creative Practice under New Media. Journal of Beijing Dance Academy, 2012,(02).

[4] L. Zhang. New Thinking on Reform of Adult Dance Teaching. Popular Literature, 2011, (10). 